Article

\title{
What Matters in Achieving Infrastructure Sustainability through Project Management Practices: A Preliminary Study of Critical Factors
}

\author{
Bin Xue ${ }^{1, *}$, Bingsheng Liu ${ }^{2}$ and Ting Sun ${ }^{3}$ \\ 1 Department of Architecture and Civil Engineering, City University of Hong Kong, Hong Kong 999077, China \\ 2 School of Public Affairs, Chongqing University, Chongqing 400044, China; bluesea_boy_1979@163.com \\ 3 GWP Engineering Ltd., Hong Kong 999077, China; Elsie.Sun@GWPengineering.com \\ * Correspondence: xuebin527@gmail.com; Tel.: +852-5427-3266
}

Received: 9 October 2018; Accepted: 21 November 2018; Published: 26 November 2018

\begin{abstract}
Sustainability has captured extensive attention in Architecture, Engineering, and Construction (AEC) industry globally. However, how to achieve Infrastructure Sustainability (IS), one the critical dimensions measuring project success, although Project Management Practices (PMPs) in international contexts remain to be explored. Based on the empirical data collected from AEC practitioners with experiences in international infrastructure projects, this research develops two conceptual frameworks for PMPs and IS using principle components analysis (PCA) and confirmatory factor analysis (CFA). Four factors are identified for measuring PMPs with a composite reliability of 0.936 - Culture, Strategy, Implementation, and Reflection-which are in analogy with the plan-do-check-action (PDCA) cycle ideology. Additionally, four metrics are also identified for IS with a composite reliability of 0.946 - Project Economy, Organizational Integration, Social Utility, and Environmental Implication - which are established from project level, organizational level, to macro level, respectively. These findings contribute to the body of knowledge of construction project management and sustainable infrastructure development by demonstrating theoretical measurement frameworks for both PMPs and IS. Potentially, the outputs of this research will generate informative insights for practitioners to improve their PMPs in the process of pursuing IS in future AEC practices.
\end{abstract}

Keywords: project management; infrastructure sustainability; critical factors; principle components analysis; confirmatory factor analysis

\section{Introduction}

The world's population is expected to reach 8.5 billion and about $60 \%$ of the population will become city dwellers [1]. To accommodate more and more city inhabitants, these cities are expanding in both size and number. By 2016, there were 512 cities with more than one million dwellers and this is projected to reach 662 cities in 2030 globally [2]. As urbanization becomes a global trend, the main concern lies in how to design a city that is comfortable to live in and serves the public successfully without compromising the benefits of later generations. Being the fundamental element that supports the smooth operation of a city, developments of sustainable infrastructures has been propelled to the center of the problem and attracted the extensive attention of stakeholders like policy-makers, scholars, the public, etc. However, the world is facing serious urbanization situations [3]. On the one hand, developing countries not only look for ways to build more infrastructures to accommodate residents but also struggle for GDP growth contributable to infrastructure construction [4]. On the other hand, developed countries are facing the reality of refurbishment or redevelopment of old infrastructures [5]. To grasp the opportunity of delivering increasing numbers of infrastructure projects globally, more and 
more construction companies with professional skills step out to compete for construction contracts in foreign markets [6]. In addition, companies are willing to take on projects in foreign countries to expand their business because of the speedy internationalization context, the lower threshold of going global, and the huge potential interests generated [7].

However, with the rapid construction of various infrastructures, scholars gradually realized the side effects it has brought to the ecological environment, which finally inflict punishment on the whole society [8-11]. Since the Brundtland Commission [12] put forward sustainable development, the concept "sustainability" has been gradually penetrated into every industry over these years. Infrastructure construction is a system engineering because it relates to a wide range of people, costs a relatively long period of construction time and a large sum of money, and stands for a very long operation time. As a consequence, whether the infrastructure projects plan to go green at the very initial stage of the project lifecycle is crucial. It will influence the usability and operability of the final products and thus impact the environment and society. Therefore, sustainable infrastructure development is now accounting for one of the most significant parts of the architecture, engineering, and construction (AEC) industry $[9,13]$.

One way to accomplish infrastructure sustainability is to improve lifecycle project management levels. Some scholars have proposed the integration of sustainability into Project Management Practices (PMPs) leading to construction project success [14,15]. As sustainability is becoming an important subject globally, it should be regarded as a new criterion for project success. PMPs, as an important facilitator for project success, are defined as the disciplined application of knowledge, skills, tools, and techniques to project activities to meet project requirements [16]. To measure infrastructure sustainability, researchers in the AEC industry have deliberated on identifying appraisal factors. For example, Shen et al. [17] set up indicator systems for infrastructure sustainability evaluation based on key indicators from three aspects, i.e., economy, society, and environment. Meng et al. [13] divided the infrastructure sustainability into internal efficiency (including buildability, maintainability, and long-term adaptability) and external efficiency (including social utility and environmental implication) from the perspective of project system.

Although integrating sustainability into PMPs has become a promising area [14,15], there still exist gaps in the current progress of sustainable infrastructure developments: short-term perspective during the planning stage; insufficient account for demand fluctuation; inconvenience for maintenance during utilization, etc. There is a lack of formal and comprehensive factor systems underlying PMPs and Infrastructure Sustainability (IS), which hinders this integration and impedes PMPs from facilitating infrastructure success in practice.

To fill the identified gaps, this research formulates the following research question: What are the factor systems for formally and comprehensively measuring PMPs and IS in international infrastructure contexts? Consequently, this research answers this question by empirically studying the critical factors for PMPs and IS constructs in international infrastructure project contexts and providing insights on how to enhance PMPs to achieve infrastructure sustainability.

\section{Research Background}

\subsection{Project Management Practices (PMPs)}

According to Schein [18], "Any social unit that has some kind of shared story will have evolved a culture". The length of the unit existence, the stability of its group members, and the emotional bond of their shared actual historical experiences determine the strength of that culture. Schein [18] further explained that the intensity of the culture could affect the effectiveness of performance, meaning the stronger the culture is, the more effectively the organization operates. Organizational culture is a value system fostered by organization leaders to normalize routines and attract new members. This can be explained by the two-tiered culture: an implicit culture that emphasizes the internal management and an explicit culture that displays the external side of the organization to the public. 
From the perspective of project management in the AEC industry, organizational culture is found to closely relate to project outcomes. Arditi et al. [19] studied the organizational culture of companies in the US and India, claiming that there is a relationship between organizational culture and project delay. They further found that organizational culture would affect the magnitude of construction delay. Liu [20] pointed out that the power of organizational culture would influence professionals' job satisfaction. However, this could be solved by enhancing people-oriented culture. To propose a guide for a construction company to develop organizational culture, Cheung et al. [21] put forward a seven-factor organizational culture framework: "Goal settings and accomplishment", "Team orientation", "Coordination and integration", "Performance emphasis", "Innovation orientation", "Members' participation", and "Reward orientation". Organizational culture is determined by the initial leader of an organization. However, as the organization develops, leadership and organizational culture are intertwined. What's more, the leadership style varies with different organizational cultural traits [22]. Additionally, different leadership styles result in different management climate, which will also impact project performance [23].

Specific step-by-step plans must be developed before action, which is called strategy. The strategy is usually neglected during the process of project management. However, Anderson \& Merna [24] pointed out that the root causes of poor project outcomes often result from poor management during the strategy formulation stage. In this regard, there is a strong need to formulate proper project strategies to guarantee the best implementation and performance. Furthermore, Artto et al. [25] categorized project strategies into four types from the perspective of the project's independence and a number of project stakeholders. They are obedient servant, independent innovator, flexible mediator, and strong leader. These project strategy types are related to the dominant leadership type. Thus, the establishment of these strategies is, to a large extent, influenced by the leadership style.

Strategy implementation is the critical step to realize the project goals regarding cost, schedule, quality, etc. Most project management literature focuses on the implementation techniques and tools [24]. However, it is far from enough to accomplish the multiple project goals. The proper allocation and utilization of resources such as human resources, materials, and equipment are of great importance. Moreover, the scope and skills of project management control would surely increase the possibility of achieving positive project outcomes [16]. In addition, Hauc \& Kovac [26] argued that the efficiency of project management can be enhanced by the implementation of the project-based strategy. Different projects have different situations. The implementation techniques adopted and transferrable knowledge utilized should be contextualized according to the situation of a single project [14]. Besides, risk challenges have been highlighted $[14,27,28]$ and the way risk management impact the project performance was explored by de Carvalho \& Junior [28].

The AEC industry has transformed from a labor-intensive industry to a knowledge-driven industry. Every experience has its lessons. Knowledge learned from one project should be applied to the other following project practices [29]. This avails decision-making smoothens management process and improves project outcomes. Thus, there is a great need to address knowledge management. In this regard, benefits could be brought to the whole project lifecycle from the planning stage to facility management stage through the coordination of different processes and reinforcement of knowledge flow among stakeholders [30]. To appraise what is obtained and what is lost, financial gains should also be evaluated. For example, the Public-Private-Partnership (PPP) scheme is nowadays a popular approach adopted in many infrastructure projects all over the world [31]. Because it eases the government's fiscal deficits and takes full advantages of specialty and resources from the private sectors. Researchers have consented to the fact that the establishment of the concession price of a PPP project is the key element to its success as it directly determines the profit of a private company [11,32-34]. To improve project management level, efforts have been spent on facilitating PM maturity and competence [14,28], PM training, management of environmental policies and standards [28], education for sustainable development [35]. These measures enhance the capability of the organization, which will make contributions to later projects. 


\subsection{Infrastructure Sustainability}

Sustainable development is defined as "development that meets the needs of the present without compromising the ability of future generations to meet their needs" [12]. This abstract and vague definition makes it hard for organizations to apply sustainable principles to real practices. Elkington [36] further elaborates sustainable success from the perspective of society, economy and environment, which is "Triple Bottom Line" (TBL), known as Triple-P (People, Planet, and Profit). The three "pillars" move constantly and emphasis may vary due to external restrictions $[37,38]$. This TBL provides a more explicit guideline for organizations to achieve sustainability. Gimenez et al. [39] studied the influence of environmental program and social practices that are implemented by corporations on each aspect of TBL and found that the former program is positively related to the achievement of all three components of TBL whereas the latter one only impacts social and environmental accomplishment.

In addition, indicators for sustainability evaluation are developed during the process of sustainable development. Many measuring systems, such as Sustainability Reporting Guidelines (SRG), Leadership in Energy and Environmental Design (LEED), are developed by some prestigious organizations. In the academic arena, researchers proposed different indicator system from a different perspective. Shen et al. [17] put forward key assessment indicators for infrastructure sustainability, which are categorized into environmental, economic, and social dimensions. Moreover, they used fuzzy set theory to come up with an algorithm to calculate the weighted sustainability scores, which helps facilitate the decision-making process. By deploying structural equation modeling, Krajangsri \& Pongpeng [40] proposed eight criteria for assessing sustainable infrastructure: environmental impacts on surrounding areas, transport, community, energy and water, location, project management, waste management, and materials and resources. They furthered their research on how sustainable infrastructure can impact the success of construction projects.

Starting from the viewpoint of the owner, Gan et al. [41] investigated causes that hinder the development of sustainable construction (SC) and identified seven major factors: economic feasibility, awareness, support from project stakeholders, legislation and regulation, operability of SC, resource risk, and project management model. From the perspective of project manager, Martens \& Carvalho [42] reviewed a large number of extant literature and classified the related indicators according to the three components of TBL and found that four factors could explain the sustainability in project management, namely, sustainable innovation business model, stakeholders management, economics, and competitive advantage, and environmental policies and resources saving. In addition, Meng et al. [13] advocated that there is a positive relationship between intellectual competence, managerial competence, and emotional and social competence of top manager and infrastructure sustainability.

With regard to the process to achieve sustainability, Dasgupta \& Tam [43] developed a normalization procedure to evaluate the sustainability of civil infrastructure systems by using two classifications of indicators: mandatory screening indicators (MSI) and judgment indicators (JI). Zhang et al. [44] measured the sustainability of construction projects to assess their sustainable development ability (SDA) and sustainable development value (SDV) for execution in every project stage by using the system dynamics approach and concluded that technology plays a more important role than a change in perception of sustainability.

\subsection{PMPs and Sustainable Project Developments}

Integration of PMPs and sustainable development is a hot topic scrutinized by academics $[45,46]$. Silvius [47] defined the integration of sustainability with project management as a new school of thought. From a holistic understanding, economic, social, and environmental perspectives are integrated with the project's product of deliverables, the process of delivering, and organization of ethics in PMPs [47]. Importance of incorporating sustainability metrics and variables in project management are cemented in business and project levels [42,48,49]. For example, Martens \& 
Carvalho [38] studied how sustainability can be introduced and integrated with PMPs of companies from different sectors. Besides, how the implementation of sustainability affects project success is also discussed. However, there still exists a gap between the perception of importance and the actual use in practice regarding introducing sustainability into PMPs [42]. Carvalho \& Rabechini [50] further tested the relationships between project sustainability management and project success using structural equation modeling. Business performances, especially in social and environmental aspects, can be enhanced by considering sustainability in PMPs [50]. Sanchez [51] examined the process of integrating sustainability issues into project management by proposing a conceptual framework for portfolio selection considering business strategy and stakeholders demands.

On a project level, Pietrosemoli \& Monroy [30] emphasized that knowledge management in PMPs, which refers to learning from previous performance and employing it into the current situation to improve outcomes, is critical in achieving sustainability goals. Robichaud \& Anantatmula [52] pointed out that traditional project management methods should be altered to complete sustainable construction projects within budget and suggestion about the early involvement of multi-disciplinary professionals to achieve financial success is made.

Although a large amount of literature has studied project management and sustainability, there is a dearth of existing literature regarding a factor system formally and comprehensively measuring PMPs and IS, which results in a broken link between PMPs and IS in the international context. Consequently, this research aims to bridge the gap between PMP and IS by empirically studying the critical influencing factors for PMPs and IS in international infrastructure project contexts. Based on the comprehensive literature review, a list of indicators for PMPs and IS were listed out in Table 1. 
Table 1. Indicators measuring Project Management Practices (PMPs) and Infrastructure Sustainability (IS) in Architecture, Engineering, and Construction (AEC) projects.

\begin{tabular}{|c|c|c|}
\hline Indicators & Definition & References \\
\hline Dominant characteristics & The most outstanding culture feature of the organization. & {$[19,53]$} \\
\hline Organizational leadership & The leadership style of the organization. & {$[19,22,53]$} \\
\hline Management of employees & How organization leaders manage their staff. & {$[19,53]$} \\
\hline Organization glue & The cohesion that gathers all the organization members. & [53] \\
\hline Strategic emphases & The critical points the organization's strategies should focus on, e.g., human or performance. & [25] \\
\hline Criteria of success & $\begin{array}{l}\text { The kind of achievement which is regarded as success once accomplished, e.g., market share improvement, staff } \\
\text { benefits enhancement, etc. }\end{array}$ & {$[54,55]$} \\
\hline Management tools \& philosophy & The rationale of project management during execution. & [56] \\
\hline Communication & Communication level and trust fostering within the project team and among stakeholders. & [57] \\
\hline Team performance & Specific steps to carry out the project. & [58] \\
\hline Tactics & The degree of acceptance to internal and external changes. & [59] \\
\hline Acceptance & Ability to adapt to internal and external changes and solve the problems caused by them. & [13] \\
\hline Reaction & The strategies should orient the project's ultimate goals & [60] \\
\hline Goal-orientation & Application level of management tools, advanced technologies, and resources. & [61] \\
\hline Performing-maturity & Utilization of management tools to achieve project targets, such as cost. & {$[14,28]$} \\
\hline Goal-realization & $\begin{array}{l}\text { Measured by cost, satisfactory productivity is work accomplished at a fair price to the owner and with a reasonable } \\
\text { profit for the contractor. }\end{array}$ & [62] \\
\hline Efficiency & Utilization of transferable skills learned from other projects. & [63] \\
\hline Skill utilization & Effective and efficient resource utilization methods. & [29] \\
\hline Resource utilization \& allocation & New technology development. & [39] \\
\hline Absorptive capacity & Management of knowledge learned. & {$[30,64]$} \\
\hline Impact on business & Core competency enhancement, market development, etc. & {$[65]$} \\
\hline Financial returns & The increase in profits benefited from efficient management. & {$[28,62]$} \\
\hline Innovation & Assessment of an individual's performance and its effect on the organization. & [30] \\
\hline Labor practice & Improvement of labors' health, working conditions, etc. & {$[38,42]$} \\
\hline Buildability & The ability to transform the project plan into reality efficiently. & [13] \\
\hline Business success & Profit maximization by minimizing the cost of producing and manufacturing and creating a reputation. & {$[39,66,67]$} \\
\hline Maintainability & The ability to maintain the infrastructure during the operation period. & [13] \\
\hline Impact on team & Employee's satisfaction level. & [58] \\
\hline Stakeholders involvement & Participation of stakeholders and relationship management among them. & {$[42]$} \\
\hline Adequate resources & Compliance with international standards. & {$[39,51,68,69]$} \\
\hline Internationalization & Balance resources and technologies across the project efficiently to meet needs as many as possible. & {$[70]$} \\
\hline 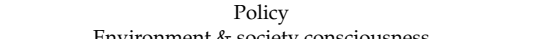 & The government's pursuit of the creation of high-level sustainable policies. & {$[38,71]$} \\
\hline Environment \& society consciousness & Foster respect for environment and society. & [38] \\
\hline Adaptability & $\begin{array}{l}\text { The infrastructure's ability to withstand and fit in external environmental disturbance and public requirement } \\
\text { changes. }\end{array}$ & [72] \\
\hline $\begin{array}{l}\text { Security } \\
\text { L }\end{array}$ & 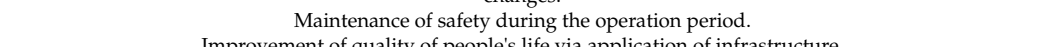 & {$[10,42]$} \\
\hline $\begin{array}{l}\text { Livability of communities } \\
\text { Productivity }\end{array}$ & $\begin{array}{l}\text { Improvement of quality of people's life via application of infrastructure. } \\
\text {. }\end{array}$ & {$[10,36,42]$} \\
\hline Productivity improvement of industries and communities & Efficiency and productivity enhanced to all the industries and communities based on the constructed infrastructure. & [8] \\
\hline Education \& training & Awareness education of sustainability for the public and stakeholders involved during the process of exercising & {$[10,42]$} \\
\hline Public support & Smooth relationship maintained with the local community during and after construction. & [38] \\
\hline Human benefit enhancement & Enhancement of people's health, wealth, etc. after infrastructure constructed. & [40] \\
\hline Natural resources & Reduction for use of the non-renewable resource, less wastage, and contamination. & {$[39,42,68]$} \\
\hline Energy & Efficient utilization of energy and no pollution. & {$[39,42]$} \\
\hline $\begin{array}{l}\text { Biodiversity } \\
\text { Eco-efficiency }\end{array}$ & Biodiversity increase and attraction to other species. & $\begin{array}{c}{[42]} \\
{[4142]}\end{array}$ \\
\hline Eco-efficiency & $\begin{array}{l}\text { Less environmental footprints. } \\
\end{array}$ & {$[41,42]$} \\
\hline
\end{tabular}




\section{Research Methodology}

An empirical survey was conducted to obtain sufficient data analyzing critical factors influencing PMPs and IS. A questionnaire was designed with statements describing 22 PMPs indicators and 21 IS indicators identified from the comprehensive literature review. A Likert scale with a 7-point threshold was adopted to collect ideas of respondents from the AEC industry. Considering that the response rate of open-ended questions is relatively lower than close-ended ones yet still an excellent way of collecting insights of respondents, a combination is adopted. A pilot study was carried out to guarantee the validity and practicality of the designed questions. Building upon this, the original questionnaire was slightly modified before mass distribution according to the pilot study refinement suggestions. Figure 1 illustrates the research methodology designed in this study.

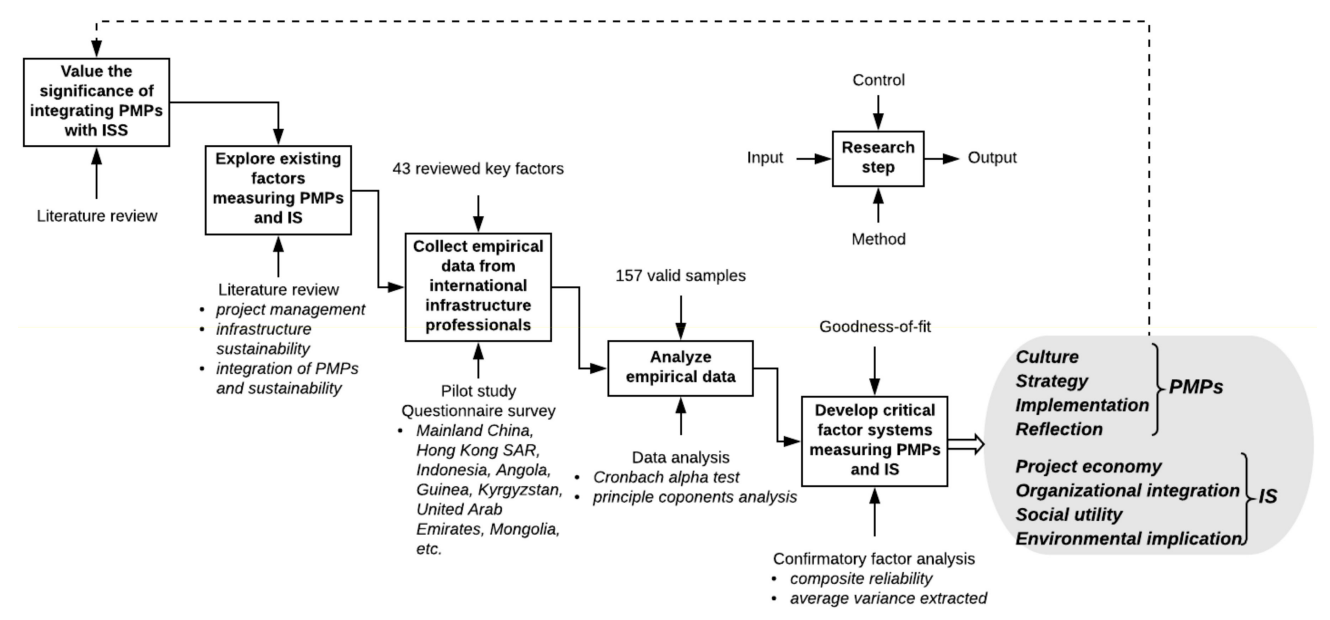

Figure 1. Empirical research design.

\subsection{Data Collection and Preprocessing}

Five hundred questionnaires were sent out by emails, letters filled with hardcopy, and web-collection application from December 2016 to March 2017 to potential respondents working in international infrastructure projects. To guarantee the quality of responses, respondent professionals were required to have participated in and completed at least one international infrastructure delivery (shown in the Appendix). In terms of generality, projects selected in this survey locate in Mainland China, Hong Kong SAR, Indonesia, Angola, Guinea, Kyrgyzstan, United Arab Emirates, Mongolia, etc. The number of questionnaires returned was 171, of which 157 was identified as valid with a response rate of $31.4 \%$. Among all the 157 respondents, 7 percent are project managers, 67 percent are managerial personnel, 24 percent are technical staff, and 3 percent do other jobs.

Furthermore, $12 \%$ of them are from the owners' company, $82 \%$ are from the contractors, and the rest of $6 \%$ are consultants. There are other salient data. For example, most of these international projects are contracted by state-owned company accounting for $72 \% .60 \%$ of the investigated infrastructure projects adopted design-bid-build (DBB) and design-build (DB). The general information of the respondents and the project profile is displayed in Table 2.

Table 2. General information about the respondents and projects.

\begin{tabular}{|c|c|c|c|c|c|c|c|c|c|c|c|}
\hline $\begin{array}{l}\text { Company } \\
\text { Type }\end{array}$ & $\begin{array}{c}\text { Ratio } \\
(\%)\end{array}$ & $\begin{array}{l}\text { Working } \\
\text { Experience } \\
\text { (Years) }\end{array}$ & $\begin{array}{c}\text { Ratio } \\
(\%)\end{array}$ & $\begin{array}{l}\text { Company } \\
\text { Role }\end{array}$ & $\begin{array}{c}\text { Ratio } \\
(\%)\end{array}$ & $\begin{array}{c}\text { Project } \\
\text { Participants }\end{array}$ & $\begin{array}{c}\text { Ratio } \\
(\%)\end{array}$ & $\begin{array}{l}\text { Delivery } \\
\text { Method }\end{array}$ & $\begin{array}{c}\text { Ratio } \\
(\%)\end{array}$ & $\begin{array}{c}\text { Infrastructure } \\
\text { Type }\end{array}$ & $\begin{array}{c}\text { Ratio } \\
(\%)\end{array}$ \\
\hline State-owned & $72 \%$ & $<5$ & $41 \%$ & Owner & $12 \%$ & $\begin{array}{l}\text { Project } \\
\text { manager }\end{array}$ & $7 \%$ & $\mathrm{DBB} / \mathrm{DB}$ & $60 \%$ & Transportation & $15 \%$ \\
\hline Foreign & $4 \%$ & $5-10$ & $30 \%$ & Contractor & $82 \%$ & $\begin{array}{c}\text { Managerial } \\
\text { personnel }\end{array}$ & $67 \%$ & $\mathrm{CM}$ & $23 \%$ & $\begin{array}{l}\text { Water/gas/ } \\
\text { electricity, } \\
\text { etc. }\end{array}$ & $44 \%$ \\
\hline Private & $21 \%$ & $10-15$ & $20 \%$ & Consultant & $6 \%$ & Technical staff & $24 \%$ & PPP & $8 \%$ & Public service & $12 \%$ \\
\hline
\end{tabular}


Before carrying out the in-depth critical factors analysis, reliability analysis should be conducted to determine whether the Likert scale is reliable [73]. The collected data were imported into IBM SPSS Statistics 22 to run a Cronbach's $\alpha$ test, which would show the internal consistency of the collected data. As a result, the value of Cronbach's $\alpha$ and standard Cronbach's $\alpha$ for question items of PMPs and IS are 0.966 and 0.969 respectively, which indicates a relatively high level of internal reliability [73-75].

\subsection{Principle Components Analysis (PCA)}

Principle components analysis (PCA) can reduce dimensions to obtain the comprehensive and key indicators that explain most of the variables of the original set. PCA was adopted in this study because it is applicable when exploring for patterns in data using variance analysis without a reliable theory articulating variable relationships [76]. This type of factor analysis could cluster these variables together in a statistical and reasonable fashion. Again, the collected data was input into SPSS to run the principal components analysis, and the outcomes for PMPs and IS are shown in the following.

In PCA, the Kaiser-Mayer-Olkin (KMO) test was adopted to measure the sampling adequacy for each constructed variable incorporated in the developed model. It examines the suitability of the collected empirical data for further factor analysis by providing variance behaviors among variables. The threshold for KMO values is set between 0.8 and 1 [77,78]. Furthermore, another measure of sampling adequacy called Bartlett's Test of Sphericity was used to examine the null hypothesis that whether the correlation matrix based on the collected data is an identity matrix, which indicates that the sample is unsuitable for structure detection. The significance level of Bartlett's Test of Sphericity is recommended to be less than $0.05[77,78]$.

\subsection{Confirmatory Factor Analysis (CFA)}

Confirmatory factor analysis (CFA) establishing constructs path models was applied to validate the confidence and reliability level of the principle components analysis results in this study. Composite reliability and average variance extracted (AVE) tests based on the factor loadings and reliability coefficients in CFA were adopted to demonstrate the model fitness and construct validity by the employment of IBM Analysis of Moment Structure (AMOS) version 21.0. The composite reliability measures the confidence level of latent variables in the established confirmatory factor model considering measurement variables' factor loadings and error variances, whose cutoff value should be 0.6 [79]. The AVE test is a convergence validity indicator. It evaluates the variances of measurement variables that can be explained by latent variables with a discriminating standard of larger than 0.5 [80]. To be precise, the larger the AVE value is, the more potential characteristics of the mutual factor construct can be effectively reflected by their measurement variables. Therefore, as long as the analysis results meet these requirements, the PCA can be consolidated and concluded reliable.

To validate the fitness level between the developed CFA path models and the collected empirical data, the goodness-of-fit test was applied for corroboration [81,82]. A good fit indicates the developed model is plausible given the collected empirical opinions. As recommended by Kline [83], goodness-of-fit indicators including the Chi-squared test, the Root mean square error of approximation (RMSEA), the comparative fit index (CFI), and the standardized root mean square residual (SRMR) have to be reported to clarify the model fit of a CFA.

\section{Results and Analysis}

The results for both PCA and CFA formalize two four-dimensional critical factor models, one for PMPs, and the other for IS.

\subsection{PCA Results for PMPs and IS}

For PMPs, the value of the KMO test for sampling adequacy is 0.884 , which is higher than 0.8 , indicating that the collected data is meritorious for factor analysis [77]. In addition, Bartlett's Test of Sphericity is 231, with the significance level of 0.000 , which implies that the population correlation 
matrix is not an identity matrix and we should be confident that factor analysis is appropriate for these data. The output of total variance explained after extraction is displayed in Table 3 with the component matrix after rotation extracted from SPSS, showing the variables onto each factor with loadings exceeding 0.50. Common themes of the 4 principal factors were identified and therefore relabeled as "Culture", "Strategy", "Implementation", and "Reflection".

By using the same method, for IS, the value of the KMO test for sampling adequacy is 0.924 (greater than 0.7) and Bartlett's Test of Sphericity is 210 (significance level: 0.000), which demonstrate that the data collected is suitable for factor analysis [77]. Table 3 shows the total variance explained and rotated component matrix of variables with loadings higher than 0.5 respectively. And the factors were labeled as "Project Economy", "Organizational Integration", "Social Utility", and "Environmental Implication".

Table 3. Analysis results of principal components for PMPs and IS.

\begin{tabular}{|c|c|c|c|c|c|}
\hline Item & No. & Components & Indicators & $\%$ of Variances & Cumulative $\%$ \\
\hline \multirow{4}{*}{ PMPs } & 1 & Culture & $\begin{array}{l}\text { Dominant characteristics } \\
\text { Organizational leadership } \\
\text { Management of employees } \\
\text { Organization glue } \\
\text { Strategic emphases } \\
\text { Criteria of success } \\
\text { Management tools \& philosophy } \\
\text { Communication }\end{array}$ & 49.834 & 49.834 \\
\hline & 2 & Strategy & $\begin{array}{c}\text { Tactics } \\
\text { Acceptance } \\
\text { Reaction } \\
\text { Goal-orientation } \\
\text { Performance maturity }\end{array}$ & 10.476 & 60.310 \\
\hline & 3 & Implementation & $\begin{array}{c}\text { Goal-realization } \\
\text { Efficiency } \\
\text { Skill utilization } \\
\text { Resource utilization/allocation } \\
\text { Innovation }\end{array}$ & 5.96 & 66.270 \\
\hline & 4 & Reflection & $\begin{array}{l}\text { Absorptive capacity } \\
\text { Impact on business } \\
\text { Financial returns } \\
\text { Team performances }\end{array}$ & 5.36 & 71.630 \\
\hline \multirow{4}{*}{ IS } & 1 & $\begin{array}{l}\text { Project } \\
\text { Economy }\end{array}$ & $\begin{array}{l}\text { Labor practice } \\
\text { Buildability } \\
\text { Business success } \\
\text { Maintainability }\end{array}$ & 41.004 & 41.004 \\
\hline & 2 & $\begin{array}{l}\text { Organizational } \\
\text { Integration }\end{array}$ & $\begin{array}{l}\text { Impact on team } \\
\text { Stakeholders involvement } \\
\text { Internationalization } \\
\text { Adequate resources }\end{array}$ & 15.084 & 56.088 \\
\hline & 3 & Social Utility & $\begin{array}{c}\text { Policy } \\
\text { Consciousness } \\
\text { Adaptability } \\
\text { Security } \\
\text { Liveability } \\
\text { Productivity } \\
\text { Education \& training } \\
\text { Public support } \\
\text { Benefit enhancement }\end{array}$ & 10.576 & 66.664 \\
\hline & 4 & $\begin{array}{l}\text { Environmental } \\
\text { Implication }\end{array}$ & $\begin{array}{c}\text { Natural resources } \\
\text { Energy } \\
\text { Biodiversity } \\
\text { Eco-efficiency }\end{array}$ & 7.652 & 74.316 \\
\hline
\end{tabular}

\subsection{CFA Results for PMPs and IS}

As for the CFA of construct PMPs, second-order CFA model was developed because of the high level of regression weights among the 4 latent factors, including Culture, Strategy, Implementation, 
and Reflection. Notably, the measurement indicator Innovation with a very low factor loading value of 0.230 in principle component factor Implementation was deleted after initial CFA modeling. After this refinement of the second-order CFA model for PMPs, Figure 2 illustrates the CFA results with modeling information including factor loadings and reliability coefficients (the variances that can be explained). Then the CFA model of construct PMPs was validated based on composite reliability and AVE tests, with the results shown in Table 4. As is demonstrated, all the composite reliability values are larger than threshold 0.6 and all the AVE values are higher than 0.5, proving the accomplishment of CFA model quality and constructs convergence validity.

Similarly, the corresponding analysis results of the second-order CFA modeling for IS and their latent and measurement variables were appraised, which are presented in Figure 3 and Table 5. Its composite reliability and AVE tests are all satisfied and achieved by applying the same criteria.

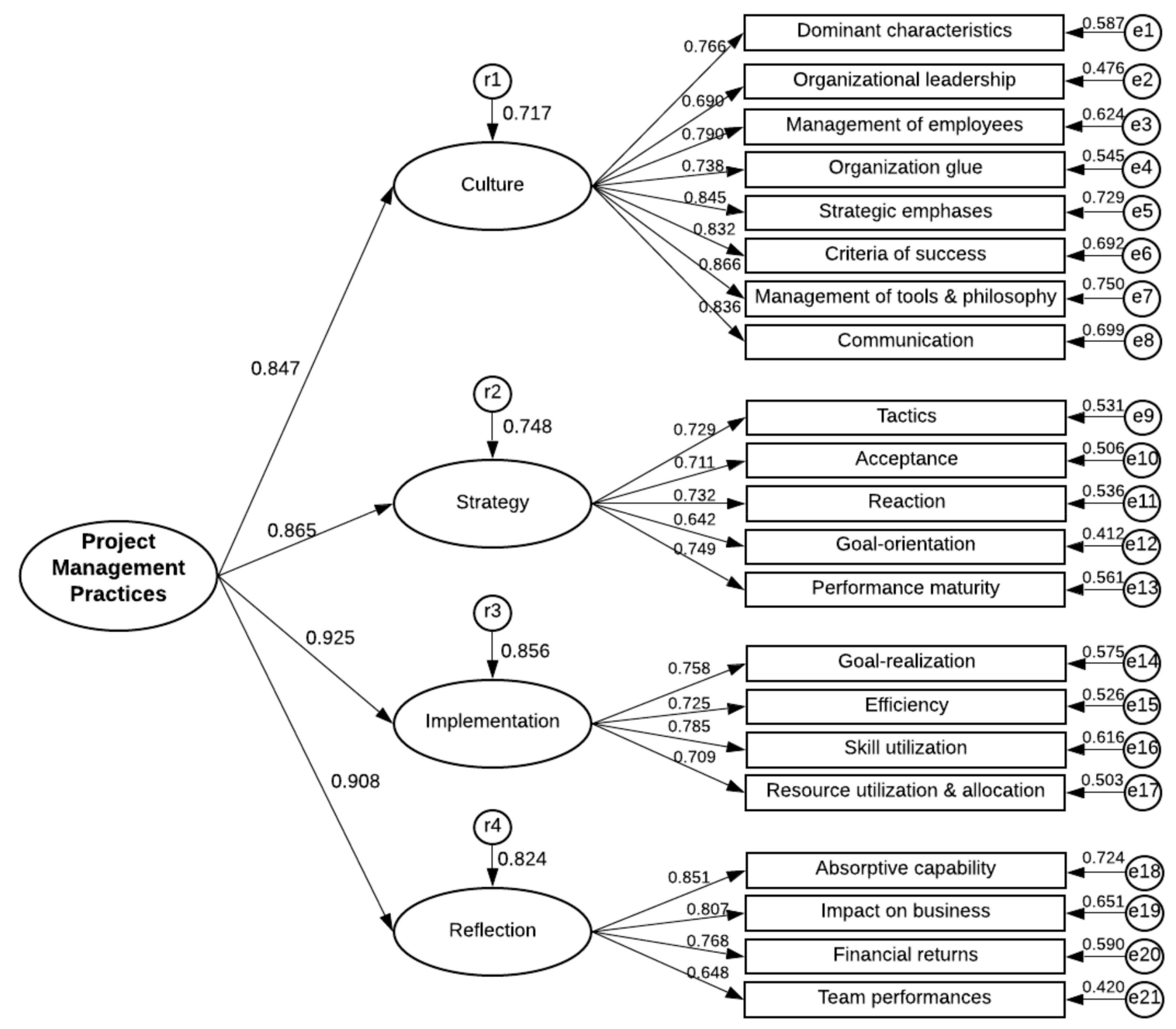

Figure 2. CFA modeling results for PMPs. 


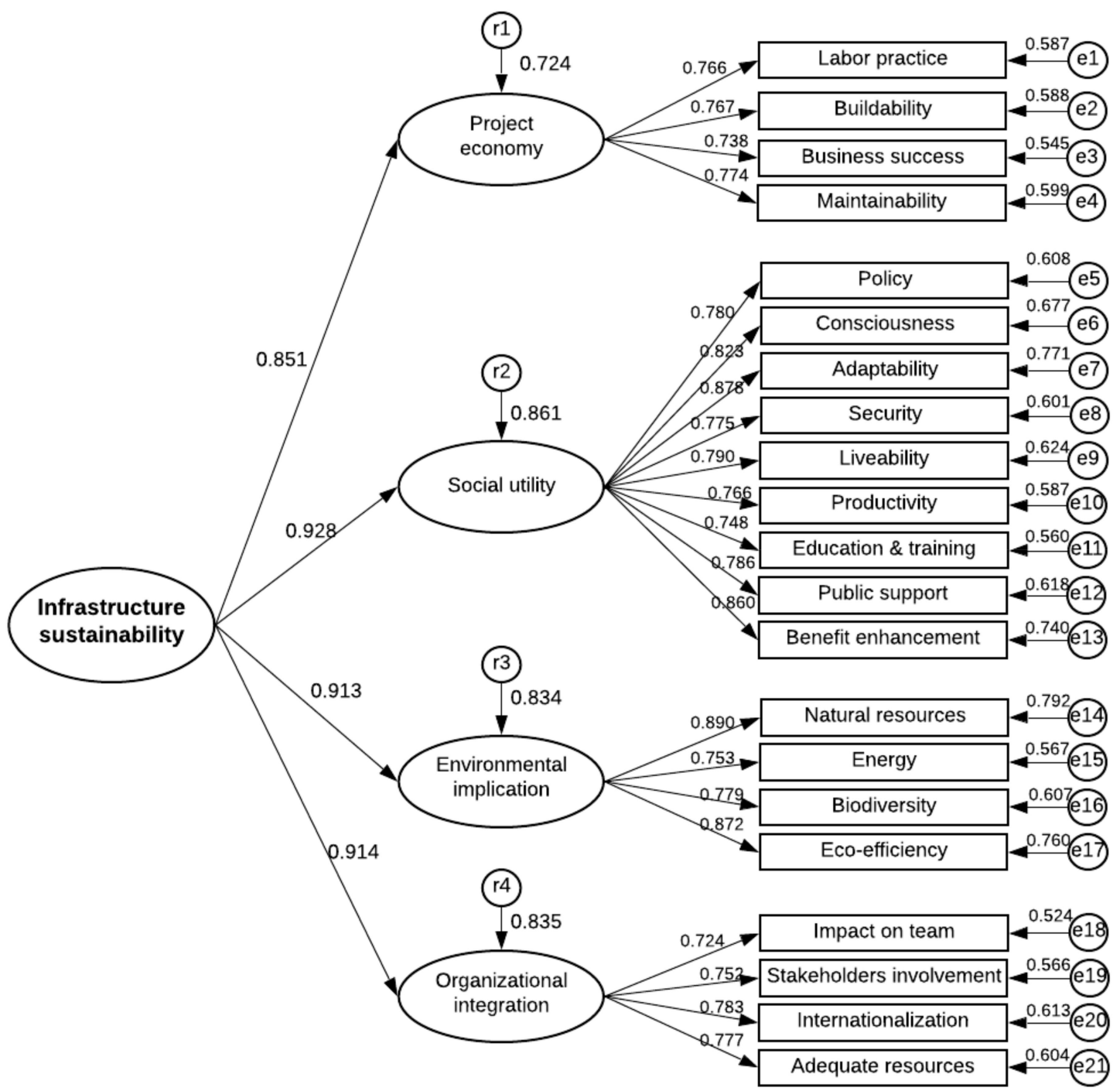

Figure 3. Confirmatory facto analysis (CFA) modeling results for IS.

Table 4. CFA reliability test results for PMPs.

\begin{tabular}{ccccc}
\hline Indicators & Factor Loading & $\begin{array}{c}\text { Reliability } \\
\text { Coefficient }\end{array}$ & $\begin{array}{c}\text { Composite } \\
\text { Reliability }\end{array}$ & $\begin{array}{c}\text { Average Variance } \\
\text { Extracted (AVE) }\end{array}$ \\
\hline Dominant characteristics & 0.766 & 0.587 & & \\
Organizational leadership & 0.690 & $0.476 *$ & & \\
Management of employees & 0.790 & 0.624 & & \\
Organization glue & 0.738 & 0.545 & & \\
Strategic emphases & 0.854 & 0.729 & & \\
Criteria of success & 0.832 & 0.692 & & \\
Management tools \& philosophy & 0.866 & 0.750 & & \\
Communication & 0.836 & 0.699 & $\mathbf{0 . 6 3 8}>\mathbf{0 . 5}$ \\
Culture & & & & \\
Tactics & 0.729 & 0.531 & & \\
Acceptance & 0.711 & 0.506 & & \\
Reaction & 0.732 & 0.536 & & \\
Goal-orientation & 0.642 & $0.412^{*}$ & & \\
Performance maturity & 0.749 & 0.561 & $\mathbf{0 . 5 0 9}>\mathbf{0 . 5}$ \\
Strategy & & & $\mathbf{0 . 6 3 8}>\mathbf{0 . 6}$ & \\
\hline
\end{tabular}


Table 4. Cont.

\begin{tabular}{ccccc}
\hline Indicators & Factor Loading & $\begin{array}{c}\text { Reliability } \\
\text { Coefficient }\end{array}$ & $\begin{array}{c}\text { Composite } \\
\text { Reliability }\end{array}$ & $\begin{array}{c}\text { Average Variance } \\
\text { Extracted (AVE) }\end{array}$ \\
\hline Goal-realization & 0.758 & 0.575 & & \\
Efficiency & 0.725 & 0.526 & & \\
Skill utilization & 0.785 & 0.616 & & \\
Resource utilization/allocation & 0.709 & 0.503 & $\mathbf{0 . 8 3 3}>\mathbf{0 . 6}$ & $\mathbf{0 . 5 5 5 > 0 . 5}$ \\
Implementation & & & & \\
Absorptive capacity & 0.851 & 0.724 & & \\
Impact on business & 0.807 & 0.651 & & \\
Financial returns & 0.768 & 0.590 & & \\
Team performances & 0.648 & $0.420^{*}$ & $\mathbf{0 . 8 5 4}>\mathbf{0 . 6}$ & \\
Reflection & & & & \\
Culture & 0.847 & 0.717 & & \\
Strategy & 0.865 & 0.748 & & \\
Implementation & 0.925 & 0.856 & $\mathbf{0 . 7 8 6}>\mathbf{0 . 5}$ \\
Reflection & 0.908 & 0.824 & $\mathbf{0 . 9 3 6}>\mathbf{0 . 6}$ & \\
& & &
\end{tabular}

Note: ${ }^{*}$ means the indicator's reliability coefficient is lower than 0.5 , which is the lowest acceptable standard value.

Table 5. CFA reliability test results for IS.

\begin{tabular}{|c|c|c|c|c|}
\hline Indicators & Factor Loading & $\begin{array}{l}\text { Reliability } \\
\text { Coefficient }\end{array}$ & $\begin{array}{l}\text { Composite } \\
\text { Reliability }\end{array}$ & $\begin{array}{c}\text { Average Variance } \\
\text { Extracted (AVE) }\end{array}$ \\
\hline Labor practice & 0.766 & 0.587 & & \\
\hline Buildability & 0.767 & 0.588 & & \\
\hline Business success & 0.738 & 0.545 & & \\
\hline Maintainability & 0.774 & 0.599 & & \\
\hline Project Economy & & & $0.847>0.6$ & $0.580>0.5$ \\
\hline Policy & 0.780 & 0.608 & & \\
\hline Consciousness & 0.823 & 0.677 & & \\
\hline Adaptability & 0.878 & 0.771 & & \\
\hline Security & 0.775 & 0.601 & & \\
\hline Liveability & 0.790 & 0.624 & & \\
\hline Productivity & 0.766 & 0.587 & & \\
\hline Education \& training & 0.748 & 0.560 & & \\
\hline Public support & 0.786 & 0.618 & & \\
\hline Benefit enhancement & 0.860 & 0.740 & & \\
\hline Social Utility & & & $0.942>0.6$ & $0.643>0.5$ \\
\hline Natural resources & 0.890 & 0.792 & & \\
\hline Energy & 0.753 & 0.567 & & \\
\hline Biodiversity & 0.779 & 0.607 & & \\
\hline Eco-efficiency & 0.872 & 0.760 & & \\
\hline Environmental Implication & & & $0.895>0.6$ & $0.682>0.5$ \\
\hline Impact on team & 0.724 & 0.524 & & \\
\hline Stakeholders involvement & 0.752 & 0.566 & & \\
\hline Internationalization & 0.783 & 0.613 & & \\
\hline Adequate resources & 0.777 & 0.604 & & \\
\hline Organizational Integration & & & $0.845>0.6$ & $0.577>0.5$ \\
\hline Project Economy & 0.851 & 0.724 & & \\
\hline Social Utility & 0.928 & 0.861 & & \\
\hline Environmental Implication & 0.913 & 0.834 & & \\
\hline \multirow{2}{*}{ Organizational Integration } & 0.914 & 0.835 & & \\
\hline & & & $0.946>0.6$ & $0.814>0.5$ \\
\hline
\end{tabular}

To corroborate the fitness validation between the proposed CFA path models for PMPs and IS and the collected empirical data, the goodness-of-fit test was performed with the discriminating criteria and outcome shown in Table 6. The values of the Normed Chi-square ratio (CMIN/DF) are 1.87 and 1.92, indicating a relatively good result using the criteria of less than 2 proposed by [82]. Meanwhile, the value of goodness-of-fit indicators of Adjusted Goodness of Fit Index (AGFI), Root Mean Square 
Error Approximation (RMSEA), Comparative Fit Index (CFI), Parsimony Normed Fit Index (PNFI), and Consistent Akaike's Information Criterion (CAIC) are all acceptable and within the standard evaluation thresholds correspondingly [81,82]. Consequently, it can be claimed that the CFA path modeling fits the empirical observations and is consolidated by satisfying the goodness-of-fit test.

Table 6. Goodness-of-fit index summary for PMPs and IS.

\begin{tabular}{|c|c|c|c|c|c|c|c|c|}
\hline \multirow[b]{2}{*}{ Index } & \multirow[b]{2}{*}{ CMIN/DF } & \multirow[b]{2}{*}{ AGFI } & \multirow[b]{2}{*}{ RMSEA } & \multirow[b]{2}{*}{ CFI } & \multirow[b]{2}{*}{ PNFI } & \multicolumn{3}{|c|}{ CAIC } \\
\hline & & & & & & Default & Saturated & Independence \\
\hline Thresholds & $<2.00$ & $>0.90$ & $<0.08$ & $>0.90$ & $>0.50$ & \multicolumn{3}{|c|}{ Default $<$ Saturated; and Default $<$ Independence } \\
\hline CFA model results for PMPs & 1.87 & 0.919 & 0.062 & 0.937 & 0.652 & 758.943 & 1379.027 & 2736.700 \\
\hline CFA model results for IS & 1.92 & 0.915 & 0.079 & 0.938 & 0.684 & 719.019 & 1379.027 & 2750.326 \\
\hline
\end{tabular}

As a result, on the one hand, measuring factors of the PMPs model are identified as "Culture", "Strategy", "Implementation", and "Reflection" and their respective explained variance are $49.834 \%$, $10.476 \%, 5.96 \%$, and $5.36 \%$, respectively. The naming of these PMP components is in accordance with the execution sequence of spanning a project lifecycle and moving from macro managerial level to micro operational level. On the other hand, measuring metrics of IS model consists of "Project Economy", "Organizational Integration", "Social Utility", and "Environmental Implication", which explained variances are $41.004 \%, 15.084 \%, 10.576 \%$, and $7.652 \%$ respectively. They were developed based on importance and influencing scale, ranging from one single project level, corporate level, social benefit all the way to the environment in which we live in, and had a significant impact on the future generation.

\section{Discussion}

Two four-dimension factor systems measuring PMPs and IS have been identified for international infrastructure developments in this research. To be specific, building upon the plan-do-check-action (PDCA) cycle ideology, a four-dimension factor system consisting of Culture, Strategy, Implementation, and Reflection is proposed to measure PMPs. Furthermore, another four-dimension factor system consisting of Project Economy, Organizational Integration, Social Utility, and Environmental Implication is developed for measuring IS, which measures the sustainability performances from project, organizational, to macro levels.

\subsection{A Four-Dimension Factor System Measuring PMPs}

Culture is the dominant characteristic of an organization in both project and corporation business management contexts. It is the criterion that distinguishes one organization from the rest. It specifies the long-term collective value of an organization, defines what is the normalized routines, and appreciates the dynamic of internal social and psychological environment. The identification of the Culture factor measuring PMPs is consistent with the evidence from Arditi et al. [19], who validated the effects of organizational culture on project performances. To begin with, when people get involved in the organization, their personal behaviors will be affected and managed by the culture of the organization. Because the culture specifies what is the goal of the company. Furthermore, organizational culture dominates the management style of leadership by defining the management boundary. Therefore, it would affect the decision-making process and management efficiency [84]. Additionally, different culture types have an influence on the project operation, such as high-efficiency working style and lifecycle project performance [13]. Besides, although culture becomes diversified over time as PMPs have been implemented, the dominant culture prevails. To this end, Culture is a virtual standard at both project and corporate levels that will guide team members' behavior in an imperceptible way through sustainability goals. It significantly affects the strategy and implementation of PMPs and thus determines the effects and performances of PMPs.

As the organizational culture has been formulated, the goals and strategies of the project should be clearly defined and laid down. Servicing as the starting point, these goal-oriented strategies display 
how to complete the project with the least compromise by incorporating the project requirements, stakeholders' demands, and corporate current situation. They affect PMPs in terms of processes and consequences, which results in positive or negative outcomes. However, all the strategies are not of equal importance. The hierarchy should be explicitly represented before implementation because resources are limited and should be utilized to maximize the possible benefits and minimize losses. Sequencing the strategies makes the implementation more effective. Besides, nothing is monotonous with the changing project environments. Therefore, strategies formulated should be flexible enough to tolerate sudden internal and external changes to guarantee sustainable success. As proposed by Morris and Jamieson [61], it is a dynamic process to manage strategies. Additionally, the level of tolerance flexibility highly depends on the organization's quick reaction to changes. This requires the staffs to own high performing maturity to respond to unexpected events. It is noteworthy that strategies are established by top managers. Because the top managers' leadership competency directly leads to the rationality of the strategies and their operational feasibility [13]. In this way, effective decision-making can assure effective PMP implementation.

Implementation is the real action leading to goals achievement in a project management context. It is the procedure to make objects of time, cost, and quality come true and to meet diverse stakeholders' requirements. Furthermore, guided by the multiple formulated strategies, emphasis should be put on the allocation and utilization of resources including human, material, and equipment. And execution schemes should be listed out to compare their economic performance to select the most suitable one. Thus, as many formulated strategies as possible could be put into practice to optimize project results. In addition, efficiency for all operations determines the right direction of all the implementing behaviors. It helps ascertain that every movement is not wasteful and of great importance to meet project targets [85]. Nevertheless, during the implementation of PMPs, managers should pay attention to the application of skills learned from previous projects to smoothen the project management process and strengthen the capacity of organizational members.

Reflection is about deep thought about what has happened during the life cycle of a project and admitting the lessons inside them. It is always crucial to have a reflection session after the completion of the project. Although reflection has been argued as a process of continuous improvement [29], little account has been taken in measuring PMPs for infrastructures. First, and maybe the most direct step is to check profitability by looking at the cash flow, rate of return, etc. As one of the important dimensions representing project sustainability, these data tell if the PMP implementation is effective or if the project performance is successful. Second, for the business success to a company, it is also critical to identify the enhancement of core competency and increase of market share. Apart from financial benefits, career development of staff plays a significant role in the future development of the company because they are the driving force for the company's operation. What they experienced and learned can be applied to new projects, which bring in new PMP basis. At corporation level, knowledge gained as an organization can be stored and utilized to later projects and descended to latter personnel, which will enforce the strength of the company. To conclude, introspection gives the whole team a chance for a summary of harvest resulting from their actions. Good or bad, lessons will be drawn from the past, which can change the appearance of the team. This will lead the PMPs to a better achievement of sustainability performances.

\subsection{A Four-Dimension Factor System Measuring IS}

Different researchers have different definitions of project success in terms of sustainability. However, most of the factor systems follow the tree pillars operationalizing sustainability from economic, social, and environmental perspectives [36]. Drawn from the empirical study of this research, three factors including project economy, social utility, and environmental implication have been formalized in accordance with the triple bottom line measurement for sustainability. To begin with, the project economy highlighting business profitability, market share increase, and business expansion are often regarded as the essential criterion because it is the fundamental incentive for 
project initiation. Only when the company envisions the bright future will it strive for the project. The in-depth feasibility study should be carried out as to whether the infrastructure development can be transformed into reality. If the project must be finished by the utilization of new technology that is expensive, it may exceed the budget line and not be sustainable in terms of project economy. This is similar to the situation of a complex infrastructure with an unachievable maintenance fee during operation and post-occupation. For international infrastructure projects, it is also critical to comply with the required international standards on the basis of their internal or domestic financial standards. Companies who want to develop trademarks and win international reputation must work even harder to do more than the standard requirements.

Furthermore, the second bottom line measuring IS highlights the benefits it can bring to society. First, the infrastructure should enhance the safety and health for the public during both construction and operation stages. Second, it is expected that contingencies happen during the long-term operation time. It is crucial that the infrastructure can resist environmental disturbances, which means the infrastructure can withstand the bad effects resulting from the disturbances and still function well. Third, as time goes by, the infrastructure function required by the social changes may vary. A social sustainable infrastructure should be able to deal with these changes. For example, the population in this district is boosting, so the passengers required to transport is more than the original amount designed for a metro project. Fourth, the infrastructure itself should be in harmonious relationship with people who live around. The sustainability it advocates raises the society environmental consciousness and acquires the public supports. Fifth, from the governmental level, the sustainable infrastructure sets an example and provokes sustainable policies. It helps obtain inspiration about sustainability and creates a higher standard for the same and similar projects. Building upon these, a social sustainable infrastructure improves the livability of communities through the creation of a better environment and will enhance human benefits, which is conducive to health and wealth. Responding to the economic bottom line, it should also be the driving force for the macroeconomy promoting local employment. It not only educates people in an imperceptible way but also has a positive influence on people's behavior toward environmental protection. Besides, it can also promote the development of the AEC industry and improve the efficiency and productivity on a social basis.

In addition, the third bottom line measuring IS is proposed as environmental implication. To reach the sustainability targets, the construction and operation of sustainable infrastructure should consider adopting environmentally friendly materials and technologies. For example, consumption of non-renewable resources must be cogitative while renewable resources have to be encouraged during PMP implementation. Apart from the input criteria, the output of the construction should not contain a large amount of wastage, which would contaminate the air, soil, and water. These contaminated elements will affect people's lives in one way or other and endanger their health. As for the energy needed to sustain the infrastructure, it should be planned during the design stage. The consumed energy resources during the operation stage should have the same characteristics that construction materials have, which is renewable, generating less wastage and contamination, and making no contributions to global warming. In addition, all the energy should be produced and used in an efficient way. For example, the power transmission project reinforces anti-leakage measures to ensure efficient power transmission. To this end, a comfortable surrounding is created, and creatures living around the infrastructure will not be disturbed, which would enhance biodiversity. Besides the downstream utilization of energy and resources, the upstream of the supply chain plays a significant role as well. What is more, it creates business opportunities for sustainable products and services and may guide some industries to a sustainable revolution, which leads to the reduction of environmental footprints.

Apart from economic, social, and environmental dimensions, this research also proposed organizational integration as a supplementary factor measuring IS for international infrastructure management. This proposal contributes to the claim from Diaz-Sarachaga et al. [86], who concluded that the management dimension has become the fourth pillar to support the triple bottom line for 
project sustainability. From the organizational level, whether the employees' career development is enhanced during and after the project is critical, as the human resource is the essential component for the delivery of projects and determines the direction of going sustainable or not. A successfully completed project should not only enhance the employees' satisfaction and give them a sense of achievement, but also cultivate their gift in accordance with their advantages and interests throughout the organizational structures. Organizations manage more than one project or project portfolio at the same time with limited resources, thus, integration of precise estimation, timely allocation, and reasonable use of resources are indispensable to attain IS. Furthermore, to take full advantage of the specialty of all the teams taking part in the project, key stakeholders should be taken onboard as early as possible in integrated meetings. All the stakeholders should make their own contributions to the project. For example, the owner should play the coordination role; the design team should come up with the optimal design scheme; the construction team should provide construction information to the design team for informed decision-making. Due to the early involvement of multiple parties, conflicts of interests may happen because of different positions and preferences. An integrated relationship maintained among these parties could help strengthen common IS objectives. Besides, people from different cultures prefer different working styles in international infrastructure contexts. This requires people participating in the project to have the strong adaptive capacity to integrate into different local cultures quickly and work with those from other cultural backgrounds. Even though multiple cultures may impede the operation, an experienced international project talent should be able to prioritize the events and normalize the working process as reflected in various PMPs. However, compared with the triple bottom line, which has been proposed and validated in various research contexts, this fourth factor measuring IS needs more echoes from more validation studies, be they empirical surveys or case studies.

\section{Conclusions and Future Works}

Infrastructure plays a crucial role in the development of new-type urbanization globally. PMPs, serving as one of the significant approaches to achieving construction project success, are widely hypothesized to have impacts on infrastructure sustainability, which is a critical dimension evaluating lifecycle infrastructure success. This research, therefore, develops two four-dimensional factor systems measuring PMPs and IS, which lays the foundation of further exploring the integrative relationships of how PMPs can lead to IS. To be specific, there are four factors identified for PMPs-Culture, Strategy, Implementation, and Reflection - which are in analogy with the plan-do-check-action (PDCA) circle ideology. Besides, another four factors are developed for IS-Project Economy, Organizational Integration, Social Utility, and Environmental Implication.

This research contributes to the theoretical integration of sustainability with project management in international infrastructure contexts by formally and comprehensively measuring IS and PMPs. A holistic perspective integrating product, process, and organizational performances of an infrastructure is highlighted in understanding PMPs. Furthermore, an integrative viewpoint combining the triple bottom line and organization integration is proposed for evaluating IS performances.

The generality of these empirical findings is claimed in collecting samples from various international infrastructure contexts. Consequently, this study not only provides steps as to how to execute excellent project management and a checklist for sustainable infrastructure developments but also generates cutting-points to solve the problems in PMPs for international infrastructure projects. Although the survey samples were collected from international infrastructure projects, further studies can be conducted to validate the generality of the two factor systems using domestic infrastructure cases. Furthermore, future works based on this study are envisioned to explore relationships of whether PMPs play significant impacts on the accomplishment of IS. To be precise, the interrelationships among PMP and IS constructs will be claimed in further empirical studies. Building upon this, AEC practitioners can be informed by knowing what should be emphasized in their current PMPs to achieve expected IS levels. 
Author Contributions: Conceptualization \& Methodology, B.X. and B.L.; Survey \& Data Analysis: T.S.; Writing and Review: B.X., B.L., and T.S.

Funding: No external funding is received for this research.

Conflicts of Interest: The authors declare no conflict of interest.

\section{References}

1. United Nations. World Urbanization Prospects; United Nations: New York, NY, USA, 2014.

2. United Nations. The World's Cities in 2016; United Nations: New York, NY, USA, 2016.

3. Cohen, B. Urbanization in developing countries: Current trends, future projections, and key challenges for sustainability. Technol. Soc. 2006, 28, 63-80. [CrossRef]

4. Rydin, Y.; Natarajan, L.; Lee, M.; Lock, S. Do local economic interests matter when regulating nationally significant infrastructure? The case of renewable energy infrastructure projects. Local Econ. 2018, 33, $269-286$. [CrossRef] [PubMed]

5. Amoah, S.T.; Owusu-Sekyere, E.; Angmor, E.N. Urban space renaissance of a developing country city. Urban Res. Pract. 2018, 1-17. [CrossRef]

6. Donaubauer, J.; Meyer, B.E.; Nunnenkamp, P. A New Global Index of Infrastructure: Construction, Rankings and Applications. World Econ. 2016, 39, 236-259. [CrossRef]

7. Bremmer, I. The new rules of globalization. Harv. Bus. Rev. 2014, 92, 103-107.

8. Benedict, M.A.; McMahon, E.T. Green Infrastructure: Linking Landscapes and Communities; Island Press: Washington, DC, USA, 2012.

9. Meng, J.; Yan, J.; Xue, B. Exploring Relationships between National Culture and Infrastructure Sustainability Using QCA. J. Constr. Eng. Manag. 2018, 144, 04018082. [CrossRef]

10. Valdes-Vasquez, R.; Klotz, L.E. Social Sustainability Considerations during Planning and Design: Framework of Processes for Construction Projects. J. Constr. Eng. Manag. 2013, 139, 80-89. [CrossRef]

11. Rouhani, O.M.; Geddes, R.R.; Gao, H.O.; Bel, G. Social welfare analysis of investment public-private partnership approaches for transportation projects. Transp. Res. Part A Policy Pract. 2016, 88, 86-103. [CrossRef]

12. World Commission on Environment and Development. Report of the World Commission on Environment and Development: Our Common Future (The Brundtland Report). Med. Confl. Surviv. 1987, 4, 300. [CrossRef]

13. Meng, J.N.; Xue, B.; Liu, B.S.; Fang, N. Relationships between top managers' leadership and infrastructure sustainability A Chinese urbanization perspective. Eng. Constr. Archit. Manag. 2015, 22, 692-714. [CrossRef]

14. Besner, C.; Hobbs, B. Contextualized project management practice: A cluster analysis of practices and best practices. Proj. Manag. J. 2013, 44, 17-34. [CrossRef]

15. Mir, F.A.; Pinnington, A.H. Exploring the value of project management: Linking Project Management Performance and Project Success. Int. J. Proj. Manag. 2014, 32, 202-217. [CrossRef]

16. Project Management Institute. A Guide to the Project Management Body of Knowledge (PMBOK®Guide); Project Management Institute: Newtown Square, PA, USA, 2013; ISBN 978-1935589679.

17. Shen, L.; Wu, Y.; Zhang, X. Key Assessment Indicators for the Sustainability of Infrastructure Projects. J. Constr. Eng. Manag. 2011, 137, 441-451. [CrossRef]

18. Schein, E.H. Organizational Culture and Leadership. Leadership 2004, 7, 437. [CrossRef]

19. Arditi, D.; Nayak, S.; Damci, A. Effect of organizational culture on delay in construction. Int. J. Proj. Manag. 2017, 35, 136-147. [CrossRef]

20. Liu, A.M.M. Culture in the Hong Kong real-estate profession: A trait approach. Habitat Int. 1999, 23, 413-425. [CrossRef]

21. Cheung, S.O.; Wong, P.S.P.; Wu, A.W.Y. Towards an organizational culture framework in construction. Int. J. Proj. Manag. 2011, 29, 33-44. [CrossRef]

22. Giritli, H.; Öney-Yazıcı, E.; Topçu-Oraz, G.; Acar, E. The interplay between leadership and organizational culture in the Turkish construction sector. Int. J. Proj. Manag. 2013, 31, 228-238. [CrossRef]

23. Gray, R.J. Organisational climate and project success. Int. J. Proj. Manag. 2001, 19, 103-109. [CrossRef] 
24. Anderson, D.K.; Merna, T. Project Management Strategy_Project management represented as a process based set of management domains and the consequences for project management strategy. Int. J. Proj. Manag. 2003, 21, 387-393. [CrossRef]

25. Artto, K.; Kujala, J.; Dietrich, P.; Martinsuo, M. What is project strategy? Int. J. Proj. Manag. 2008, 26, 4-12. [CrossRef]

26. Hauc, A.; Kovač, J. Project management in strategy implementation-Experiences in Slovenia. Int. J. Proj. Manag. 2000, 18, 61-67. [CrossRef]

27. Chou, J.; Leatemia, G. Critical process and factors for ex-post evaluation of Public-Private Partnership infrastructure projects in Indonesia. J. Manag. Eng. 2016, 32, 1-11. [CrossRef]

28. De Carvalho, M.M.; Patah, L.A.; de Souza Bido, D. Project management and its effects on project success: Cross-country and cross-industry comparisons. Int. J. Proj. Manag. 2015, 33, 1509-1522. [CrossRef]

29. Kozak-Holland, M.; Procter, C. Florence Duomo project (1420-1436): Learning best project management practice from history. Int. J. Proj. Manag. 2014, 32, 242-255. [CrossRef]

30. Pietrosemoli, L.; Monroy, R.C. The impact of sustainable construction and knowledge management on sustainability goals. A review of the Venezuelan renewable energy sector. Renew. Sustain. Energy Rev. 2013, 27, 683-691. [CrossRef]

31. Osei-Kyei, R.; Chan, A.P.C. Review of studies on the critical success factors for public-private partnership (PPP) projects from 1990 to 2013. Int. J. Proj. Manag. 2015, 33, 1335-1346. [CrossRef]

32. Xu, Y.; Sun, C.; Skibniewski, M.J.; Chan, A.P.C.; Yeung, J.F.Y.; Cheng, H. Developing a concession pricing model for PPP highway projects. Int. J. Proj. Manag. 2012, 16, 201-217. [CrossRef]

33. Xu, Y.; Sun, C.; Skibniewski, M.J.; Chan, A.P.C.; Yeung, J.F.Y.; Cheng, H. System Dynamics (SD)-based concession pricing model for PPP highway projects. Int. J. Proj. Manag. 2012, 30, 240-251. [CrossRef]

34. Ashuri, B.; Kashani, H.; Molenaar, K.R.; Lee, S.; Lu, J. Risk-Neutral Pricing Approach for Evaluating BOT Highway Projects with Government Minimum Revenue Guarantee Options. J. Constr. Eng. Manag. 2012, 138, 545-557. [CrossRef]

35. Bärlund, K. Sustainable development-Concept and action

36. Elkington, J. Cannibals with Forks: The Triple Bottom Line of 21st Century Business; Capstone: Oxford, UK, 1997; ISBN 190096127X.

37. Shenhar, A.; Dvir, D. The Diamond Approach to Successful Growth and Innovation; Harvard Business Press: Boston, MA, USA, 2007; ISBN 1591398002.

38. Martens, M.L.; Carvalho, M.M. Key factors of sustainability in project management context: A survey exploring the project managers' perspective. Int. J. Proj. Manag. 2017, 35, 1084-1102. [CrossRef]

39. Gimenez, C.; Sierra, V.; Rodon, J. Sustainable operations: Their impact on the triple bottom line. Int. J. Prod. Econ. 2012, 140, 149-159. [CrossRef]

40. Krajangsri, T.; Pongpeng, J. Effect of Sustainable Infrastructure Assessments on Construction Project Success Using Structural Equation Modeling. J. Manag. Eng. 2017, 33, 04016056. [CrossRef]

41. Gan, X.; Zuo, J.; Ye, K.; Skitmore, M.; Xiong, B. Why sustainable construction? Why not? An owner's perspective. Habitat Int. 2015, 47, 61-68. [CrossRef]

42. Martens, M.L.; Carvalho, M.M. The challenge of introducing sustainability into project management function: Multiple-case studies. J. Clean. Prod. 2016, 117, 29-40. [CrossRef]

43. Dasgupta, S.; Tam, E.K. Indicators and framework for assessing sustainable infrastructure. Can. J. Civ. Eng. 2005, 32, 30-44. [CrossRef]

44. Zhang, X.; Wu, Y.; Shen, L.; Skitmore, M. A prototype system dynamic model for assessing the sustainability of construction projects. Int. J. Proj. Manag. 2014, 32, 66-76. [CrossRef]

45. Silvius, A.J.G.; Schipper, R.; Nedeski, S. Sustainability in Project Management: Reality Bites. PM World J. 2013, 2, 1-183. [CrossRef]

46. Gareis, R.; Huemann, M.; Martinuzzi, A. Relating Sustainable Development and Project Management: A Conceptual Model. In Proceedings of the PMI Research and Education Conference, Washington, DC, USA, 10-14 July 2010; pp. 1-17.

47. Silvius, G. Sustainability as a new school of thought in project management. J. Clean. Prod. 2017, 166, 1479-1493. [CrossRef]

48. Singh, R.K.; Murty, H.R.; Gupta, S.K.; Dikshit, A.K. An overview of sustainability assessment methodologies. Ecol. Indic. 2012, 15, 281-299. [CrossRef] 
49. Larrinaga, C. Sustainability reporting: Insights from neo-institutional theory. Routledge 2007, 1-20. [CrossRef]

50. Carvalho, M.M.; Rabechini, R. Can project sustainability management impact project success? An empirical study applying a contingent approach. Int. J. Proj. Manag. 2017, 35, 1120-1132. [CrossRef]

51. Sánchez, M.A. Integrating sustainability issues into project management. J. Clean. Prod. 2015, 96, 319-330. [CrossRef]

52. Robichaud, L.B.; Anantatmula, V.S. Greening project management practices for sustainable construction. J. Manag. Eng. 2011, 27, 48-57. [CrossRef]

53. Cameron, K.S.; Quinn, R.E. An Introduction to changing organisational culture: Based on the competing values framework. Diagn. Chaning Organ. Cult. 2011, 1-12.

54. Atkinson, R. Project management: Cost, time and quality, two best guesses and a phenomenon, its time to accept other success criteria. Int. J. Proj. Manag. 1999, 17, 337-342. [CrossRef]

55. Atkinson, A.R.; Westall, R. The relationship between integrated design and construction and safety on construction projects. Constr. Manag. Econ. 2010, 28, 1007-1017. [CrossRef]

56. Chan, A.; Scott, D.; Chan, A. Factors affecting the success of a construction project. J. Constr. Eng. Manag. 2004, 130, 153-155. [CrossRef]

57. Sanvido, B.V.; Member, A.; Grobler, F.; Parfitt, K.; Guvenis, M.; Coyle, M. Critical Success Factors for Construction Projects. J. Constr. Eng. Manag. 1992, 118, 94-111. [CrossRef]

58. Miles, S.J.; Mangold, G. The impact of team leader performance on team member satisfaction: The subordinate's perspective. Team Perform. Manag. An Int. J. 2002, 8, 113-121. [CrossRef]

59. Konanahalli, A.; Oyedele, L.O. Emotional intelligence and British expatriates' cross-cultural adjustment in international construction projects. Constr. Manag. Econ. 2016, 34, 751-768. [CrossRef]

60. Ozorovskaja, R.; Voordijk, J.T.; Wilderom, C.P. Leadership and cultures of Lithuanian and Dutch construction firms. J. Constr. Eng. Manag. 2007, 133, 900-911. [CrossRef]

61. Morris, P.; Jamieson, A. Linking Corporate Strategy to Project Strategy via Portfolio and Program Management. Proj. Manag. J. 2005, 28.

62. De Carvalho, M.M.; Junior, R.R. Impact of risk management on project performance: The importance of soft skills. Int. J. Prod. Res. 2015, 53, 321-340. [CrossRef]

63. Biggart, N.W. Constructing Green: The Social Structures of Sustainability; MIT Press: Cambridge, MA, USA, 2013.

64. Vicente-Oliva, S.; Martínez-Sánchez, Á.; Berges-Muro, L. Research and development project management best practices and absorptive capacity: Empirical evidence from Spanish firms. Int. J. Proj. Manag. 2015, 33, 1704-1716. [CrossRef]

65. Robert, O.-K.; Dansoh, A.; Ofori-Kuragu, J.K. Reasons for adopting Public-Private Partnership (PPP) for construction projects in Ghana. Int. J. Constr. Manag. 2017, 14, 227-238. [CrossRef]

66. Cruz, J.M.; Wakolbinger, T. Multiperiod effects of corporate social responsibility on supply chain networks, transaction costs, emissions, and risk. Int. J. Prod. Econ. 2008, 16, 61-74. [CrossRef]

67. Fombrun, C.J. A World of Reputation Research, Analysis and Thinking-Building Corporate Reputation through CSR Initiatives: Evolving Standards. Corp. Reput. Rev. 2005, 8, 7-12. [CrossRef]

68. Hart, S.L. A natural-resource-based view of the firm. Acad. Manag. Rev. 1995, 20, 986-1014. [CrossRef]

69. Starik, M.; Rands, G.P. Weaving an integrated web: Multilevel and multisystem perspectives of ecologically sustainable organizations. Acad. Manag. Rev. 1995, 20, 908-935. [CrossRef]

70. Willar, D.; Trigunarsyah, B.; Coffey, V. Organisational culture and quality management system implementation in Indonesian construction companies. Eng. Constr. Archit. Manag. 2016, 23, 114-133. [CrossRef]

71. Choguill, C.L. Ten steps to sustainable infrastructure. Habitat Int. 1996, 20, 389-404. [CrossRef]

72. Salman, A.F.M.; Skibniewski, M.J.; Basha, I. BOT Viability Model for Large-Scale Infrastructure Projects. J. Constr. Eng. Manag. 2007, 133, 50-63. [CrossRef]

73. Bland, J.M.; Altman, D.G. Statistics notes: Cronbach's alpha. BMJ 1997, 314, 572. [CrossRef] [PubMed]

74. Ott, R.L.; Longnecker, M. An Introduction to Statistical Methods and Data Analysis, 7th ed.; Brooks Cole: Boston, MA, USA, 2016; ISBN 978-1305269477.

75. Streiner, D.L. Being inconsistent about consistency: When coefficient apha does and doesn't matter. J. Pers. Assess. 2003, 80, 217-222. [CrossRef] [PubMed]

76. Tabachnick, B.G.; Fidell, L.S. Using Multivariate Statistics, 6th ed.; Harper Row: New York, NY, USA, 2012. 
77. Hutcheson, G.; Sofroniou, N. The Multivariate Social Scientist; SAGE Publications: Thousand Oaks, CA, USA, 1999; ISBN 0857028073.

78. Rosenbaum, P.R.; Rubin, D.B. The central role of the propensity score in observational studies for causal effects. Biometrika 1983, 70, 41-55. [CrossRef]

79. Raykov, T. Estimation of Composite Reliability for Congeneric Measures. Appl. Psychol. Meas. 1997, 21, 173-184. [CrossRef]

80. Fornell, C.; Larcker, D.F. Structural Equation Models with Unobservable Variables and Measurement Error: Algebra and Statistics. J. Mark. Res. 1981, 18. [CrossRef]

81. Schermelleh-Engel, K.; Moosbrugger, H.; Müller, H. Evaluating the fit of structural equation models: Tests of significance and descriptive goodness-of-fit Measures. Methods Psychol. Res. Online 2003, 8, 23-74. [CrossRef]

82. Planing, P. Innovation Acceptance: The case of Advanced Driver-Assistance Systems; Springer Fachmedien Wiesbaden: Wiesbaden, Germany, 2014; ISBN 9783658050054.

83. Kline, R.B. Principles and Practice of Structural Equation Modelling; Guilford Publications: New York, NY, USA, 2011; ISBN 978-1-60623-876-9.

84. Naoum, S.G.; Alyousif, A.-R.T.; Atkinson, A.R. Impact of National Culture on the Management Practices of Construction Projects in the United Arab Emirates. J. Manag. Eng. 2013, 31, 04014057. [CrossRef]

85. Serrador, P.; Turner, R. The relationship between project success and project efficiency. Proj. Manag. J. 2015, 46, 30-39. [CrossRef]

86. Diaz-Sarachaga, J.M.; Jato-Espino, D.; Alsulami, B.; Castro-Fresno, D. Evaluation of existing sustainable infrastructure rating systems for their application in developing countries. Ecol. Indic. 2016, 71, 491-502. [CrossRef]

(C) 2018 by the authors. Licensee MDPI, Basel, Switzerland. This article is an open access article distributed under the terms and conditions of the Creative Commons Attribution (CC BY) license (http:/ / creativecommons.org/licenses/by/4.0/). 